\title{
SELF-COMPATIBILITY IN MODERN HYBRIDS OF SUNFLOWER (Helianthus annuus L.). FRUIT SET IN OPEN AND SELF-POLLINATED (BAG ISOLATED) PLANTS GROWN IN TWO DIFFERENT LOCATIONS
}

\author{
Astiz, V. ${ }^{*}{ }^{1}$ Iriarte, L.A. ${ }^{2}$, Flemmer, A. ${ }^{1}$ and Hernández, L.F. ${ }^{1,3}$ \\ ${ }^{1}$ Laboratorio de Morfología Vegetal. Departamento de Agronomía, \\ Universidad Nacional del Sur. Bahía Blanca, 8000 \\ ${ }^{2}$ Chacra Experimental de Barrow, MAA-INTA, Tres Arroyos \\ ${ }^{3}$ Comisión de Investigaciones Científicas de la Pcia. de Buenos Aires (CIC). \\ La Plata, 1900, Argentina
}

Received: December 5, 2010 Accepted: March 15, 2011

\section{SUMMARY}

The increase in sunflower yield due to the active participation of honey bees (Apis melifera L.) in crop pollination has been demonstrated in previous studies. However, this fact is more evident in earlier commercial hybrids. There are reports that suggest that bees are not required in modern commercial hybrids where a high level of self-compatibility occurs.

The purpose of this study was to define formation capacity of fully developed fruits (FDF) and incompletely developed fruits (IDF) in two modern sunflower hybrids exposed to open and closed pollination. Two hybrids, one of half cycle and the other of short cycle, labelled HA and HB respectively, were submitted to two pollination regimes: auto-pollination (bagged treatment) where the heads were covered with mesh bags from the first anthesis (FA) to the last anthesis (LA), avoiding the action of pollinators and open pollination (open treatment). The study was conducted during three consecutive years in two different locations. In the first year, the experimental plots were located at the Chacra experimental Barrow (Tres Arroyos; $38^{\circ} 20^{\prime}$ S; $60^{\circ} 13^{\prime} \mathrm{W}$ ) and in the second and third year at the experimental field of Universidad Nacional del Sur, (Bahía Blanca; $38^{\circ} 45^{\prime} \mathrm{S} ; 62^{\circ} 11^{\prime} \mathrm{W}$ ), reaching an average plant density of 60.000 plants/ha. During the second year treatments were conducted only on the HA and during the third year only on the HB.

The number of FDF and IDF, in the three experiments on both sites did not show significant differences among treatments. Nevertheless, a non-significant different response in the number of FDF and IDF was observed during two years, probably as a result of changes in environmental conditions during the anthesis period.

We conclude that, due to the effect of a high level of self-compatibility, no differences in the generation of fully developed fruits can be observed when plants of modern commercial sunflower hybrids are excluded from pollinators.

Key words: fruit set, Helianthus annuus, pollination, self compatibility, sunflower, yield

* Corresponding author: Fax: +54-0291-4595127; e-mail: vastiz@criba.edu.ar 


\section{INTRODUCTION}

The occurrence of incompletely developed fruits, fruits with absent or poorly developed embryo, a detriment of fully developed fruits, adversely affect sunflower yield (Lindström et al., 2004). Failures in pollination, fertilization and physiological defects in the ovary and embryo either genotypic and/or environmentally induced, such as water stress in anthesis and supra-optimal temperatures after pollination or post-fertilization, are among the most common reasons for the formation of this type of fruits (DeGrandi-Hoffman and Chambers, 2006).

Until the 1960's the sunflower cultivars were open-pollinated and cross-pollinated mostly by insects. These cultivars, along with the wild species, were highly self-incompatible. Sunflower, as well as other species of Asteraceae family has a sporophytic self-incompatibility system. However, this system in sunflower is underdeveloped, serving more to reduce than to prevent fertilization (FernándezMartínez and Knowles, 1978).

Nowadays, self-compatibility in sunflower hybrids ranges from 15 to $95 \%$ with an average percentage of $68 \%$. In particular, current commercial sunflower varieties have the highest degree of self-compatibility. However, environmental conditions can influence the level of self-fertility expressed (Snow et al., 1998). So, failures in self-pollination and fertilization usually observed are generally the result of anatomical, morphological (asynchrony between pollen maturation and stigma receptivity [protandry]) and environmental barriers (excessive air relative humidity or rain, or air temperature above $30^{\circ} \mathrm{C}$ during pollination) affecting pollen viability, stigma receptivity and pollen tube growth. Additionally, proper characteristics of the genotype may confer a significant degree (50-60\%) of self-incompatibility.

The visit of pollinators may be essential for seed production during sunflower anthesis, since when androsterile lines (no pollen production) are used, the pollen must be transported from the androfertile florets to the stigma of androsterile ones. However, the importance of pollinators in androfertile oil hybrids has not been totally established.

It has been documented that sunflower production is increased when honey bees (Apis melifera L.) participate actively in crop pollination (see DeGrandi-Hoffman and Chambers, 2006 and references therein). This fact was highly evident for early commercial genotypes (Iriarte and Valetti, 1994a, 1994b). Other studies suggest that pollinators would not be necessary in modern commercial cultivars, where a high degree of self-compatibility occurs. In these cultivars the degree of self-compatibility has been improved, even though they show considerable differences which are not always documented (Snow et al., 1998; Myers, 2002, cited by DeGrandiHoffman and Chambers, 2006).

The aim of this work was to study fruit set in the sunflower head of two modern hybrids grown in two agrosites. The plants were exposed to pollinators in a selec- 
tive form (open and close pollination) and the production capacity of fully developed fruits and incompletely developed fruits was defined.

\section{MATERIALS AND METHODS}

Two sunflower hybrids provided by Monsanto Argentina were used: one of half cycle and the other one of short cycle. Due to a confidentiality commitment with the seed company which provided the hybrids for this work, the two ones were labelled $\mathrm{HA}$ and $\mathrm{HB}$.

The study was conducted during three consecutive years in two different locations. The experimental plots were always near domestic bee (Apis mellifera L.) colonies. This ensured that flower visits were highly intense during anthesis. Climate data (air relative humidity, rainfall, air temperature and solar radiation) was continuously recorded during the crop growth each year.

The experiments were laid out in a randomized complete block design with four replicates. The crop was cultivated according to conventional agronomical practices and weeds and insects were adequately controlled. Two treatments were established: bagged plants and open pollinates plants. In bagged plants, heads were covered with fine mesh bags to avoid the action of pollinators until the corolla of the central florets were withered. In open pollinated plants capitula were left uncovered. The bagged treatment finished at early R9 stage (Schneiter and Miller, 1981). From that stage on, heads were covered with anti bird mesh bags to avoid damage until the harvest period.

The first experiment was conducted at the Chacra Experimental Barrow (MAAINTA, Tres Arroyos; $38^{\circ} 20^{\prime} \mathrm{S}, 60^{\circ} 13^{\prime}$ W.). Both hybrids (HA and HB) were grown in plots with 3 rows of $6 \mathrm{~m}$ and an intra-row spacing of $0,70 \mathrm{~m}$. At flowering the average plant density was 60.000 plants/ha. Four plants per plot were identified and labelled for each genotype and treatment at R5.1 stage (Schneiter and Miller, 1981).

In the second year only the HA hybrid was studied while in the third year the HB hybrid was the unique crop grown. During the last two years, the experiment was carried out at the experimental field of Universidad Nacional del Sur $\left(38^{\circ} 45^{\prime}\right.$ S; $62^{\circ} 11^{\prime} \mathrm{W}$ ) in plots where plants were grown in 3 rows of $12 \mathrm{~m}$ in length with an intra-row spacing of $0.70 \mathrm{~m}$. During the stage of flowering the average plant density was 60.000 plants/ha. At R5.1 (Schneiter and Miller, 1981) plants were randomly selected and labelled. 16 and 20 plants per plot at each treatment were selected in the second and third year, respectively.

The harvest was conducted during those three years with a fruit humidity content ranging from 13 to $18 \%$. The heads harvested from both treatments were analysed in the laboratory. The fruits were separated into fully developed fruits (FDF) and incompletely developed fruits (IDF). The weight of the FDF per head was obtained.

A simple analysis of variance (ANOVA) was carried out for each variable and year using the Infostat Profesional software (Di Rienzo et al., 2008). 


\section{RESULTS}

The results from the analysis of the number of FDF and IDF during the three years and in the two sunflower hybrids studied are shown in Table 1.

Table 1: Number of FDF, IDF and individual weight of the fruits (mg) for each treatment and hybrid (HA, HB), in the three years of assays. Values followed by the same letter do not differ significantly $(\mathrm{p}<0,05)$

\begin{tabular}{|c|c|c|c|c|c|c|}
\hline \multirow{2}{*}{$\begin{array}{l}\text { First year } \\
\text { Treatments/ Hybrids }\end{array}$} & \multicolumn{2}{|c|}{ FDF Number } & \multicolumn{2}{|c|}{ IDF Number } & \multicolumn{2}{|c|}{ Weight per fruit (mg) } \\
\hline & $\mathrm{HA}$ & $\mathrm{HB}$ & $\mathrm{HA}$ & $\mathrm{HB}$ & $\mathrm{HA}$ & $\mathrm{HB}$ \\
\hline Open & $1285 a$ & $1249 a$ & $363 \mathrm{a}$ & $309 a$ & $28.5 \mathrm{a}$ & $29.0 \mathrm{a}$ \\
\hline Bagged & $1219 a$ & $1343 a$ & $276 a$ & $546 a$ & $32.4 \mathrm{a}$ & $29.5 \mathrm{a}$ \\
\hline Second year & \multicolumn{2}{|c|}{ FDF Number } & \multicolumn{2}{|c|}{ IDF Number } & \multicolumn{2}{|c|}{ Weight per fruit (mg) } \\
\hline Treatments/ Hybrids & \multicolumn{2}{|c|}{$\mathrm{HA}$} & \multicolumn{2}{|c|}{$\mathrm{HA}$} & \multicolumn{2}{|c|}{$\mathrm{HA}$} \\
\hline Open & \multicolumn{2}{|c|}{$1345 a$} & \multicolumn{2}{|c|}{$252 a$} & \multicolumn{2}{|c|}{$50.0 \mathrm{a}$} \\
\hline Bagged & \multicolumn{2}{|c|}{$1240 \mathrm{a}$} & \multicolumn{2}{|c|}{$303 a$} & \multicolumn{2}{|c|}{$48.4 \mathrm{a}$} \\
\hline Third year & \multicolumn{2}{|c|}{ FDF Number } & \multicolumn{2}{|c|}{ IDF Number } & \multicolumn{2}{|c|}{ Weight per fruit (mg) } \\
\hline Treatments/ Hybrids & \multicolumn{2}{|c|}{$\mathrm{HB}$} & \multicolumn{2}{|c|}{$\mathrm{HB}$} & \multicolumn{2}{|c|}{$\mathrm{HB}$} \\
\hline Open & \multicolumn{2}{|c|}{$1201 \mathrm{a}$} & \multicolumn{2}{|c|}{$216 a$} & \multicolumn{2}{|c|}{$51.2 \mathrm{a}$} \\
\hline Bagged & \multicolumn{2}{|c|}{$1105 a$} & \multicolumn{2}{|c|}{$361 \mathrm{a}$} & \multicolumn{2}{|c|}{$60.6 \mathrm{a}$} \\
\hline
\end{tabular}

Maximum and minimum temperatures and the rainfall recorded between pre anthesis and the harvest of the plants during the three years of the assay and their correspondence with the time interval between first anthesis (FA) and last anthesis (LA) for each hybrid are shown in Figure 1.
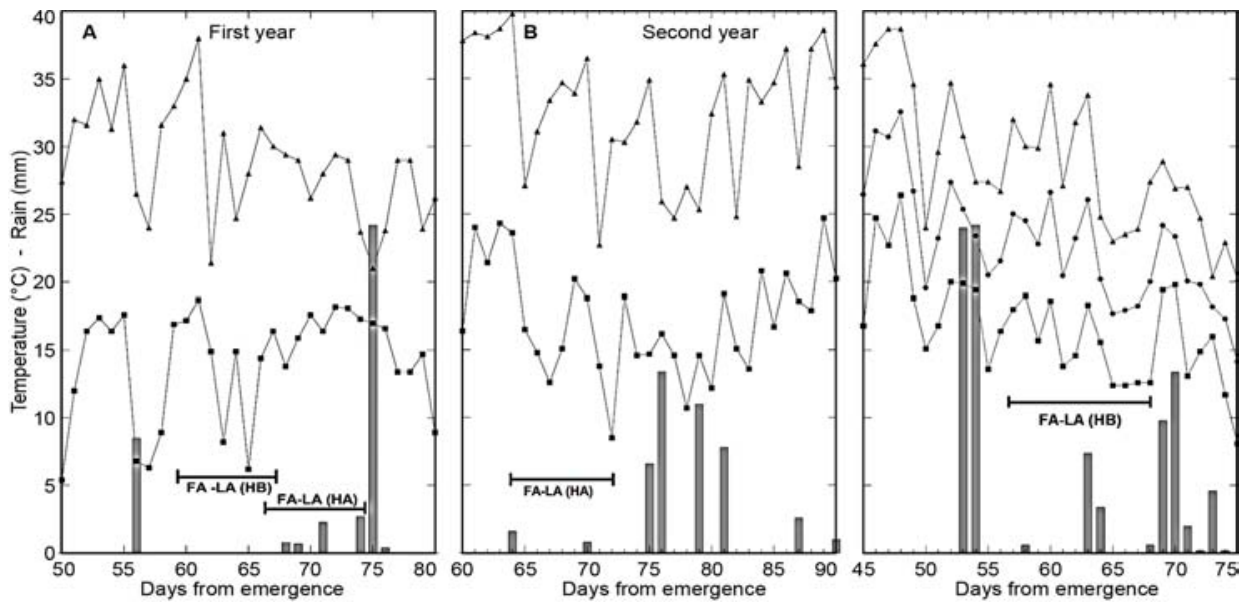

Figure 1: Maximum (- $\left.\mathbf{\Delta}_{-}\right)$and minimum (- -) temperatures $\left({ }^{\circ} \mathrm{C}\right)$ and rainfall (grey bars; $\mathrm{mm}$ ) recorded during the period in the crop cycle between the first anthesis (FA) and the physiological maturity. The arrows indicate different moments of the crop growth and of the analysis. LA: last anthesis; HA: hybrid A, HB: hybrid B. 
In the first year, no significant differences $(p<0,05)$ in the number of FDF and IDF among the treatments were observed. No genotype-treatment interactions could be determined (Table 1). However, HB hybrid showed a higher number of FDF with higher weights in bagged plants (Table 1) while HA hybrid showed a lower number of FDF with higher individual weights, for the same treatment.

During the anthesis period of HB no rainfall occurred (Figure 1a). Before harvest of HA's capitula, rainfall reached $24.2 \mathrm{~mm}$ but most of the florets of this hybrid had already finished releasing pollen (Figure 1a).

Average air temperature over the whole experiment during the first year was $19.4^{\circ} \mathrm{C}$ (Figure 1a), with two maximums of $38.4^{\circ} \mathrm{C}$ and $38^{\circ} \mathrm{C}$ approximately 10 days before HB's anthesis, 48 days from emergence (DFE) and 3 days before the starting of HB's anthesis, respectively. It is known that temperatures higher than $30^{\circ} \mathrm{C}$ can reduce viability of pollen germination as well as stigma receptivity (Rosell et al., 1999, cited by Degrandi-Hoffman and Chambers, 2006).

It is possible to speculate that considering the climate conditions during our experiments, the bagged heads, independently of the hybrid they belonged to, presented higher possibilities of producing fully developed fruits than uncovered capitula because they were not exposed directly to the action of high temperatures, as might have been during the day (Ploschuck and Hall, 1995).

The results obtained during the experiment conducted in the second year were similar to those obtained in the first year. In fact, as shown in Table 1, no significant differences were observed in the variables determined between the two treatments. However, individual weight of set fruits were slightly higher in bagged than in open treatment. Average air temperature in the second year was $23.6^{\circ} \mathrm{C}$ during the whole experiment. Maximum values $\left(38.4\right.$ and $39.8^{\circ} \mathrm{C}$ ) occurred between 61 and $64 \mathrm{DFE}$ (Figure 1b). Additionally, during the period of pollen emission (between 66 to $70 \mathrm{DFE}$ ) temperatures higher than $30^{\circ} \mathrm{C}$ were measured (Figure $1 \mathrm{~b}$ ). These values were observed from the second to the fifth day after FA with an average temperature of $34.6 \pm 1.36^{\circ} \mathrm{C}$. The possibility that this could have reduced pollen viability and germination and stigma receptivity (Rosell et al., 1999, cited by Degrandi-Hoffman and Chambers, 2006), was not expressed in a reduction of FDF (Table 1).

Low rainfall was observed during the whole experiment in the second year (Figure 1b). However, after crop emergence and during the vegetative stage, heavy rains occurred: 15, 18.2 and $11.6 \mathrm{~mm}$ at 3, 27 and $46 \mathrm{DFE}$, respectively. After reaching FA, rainfall occurred at 76 and $79 \mathrm{DFE}$, with records of 13.4 and $11.0 \mathrm{~mm}$, respectively. However, since this events occurred near the end of the treatments (Figure 1b), they were not likely to affect pollination. Finally, in the third year no significant differences in the number of FDF and IDF or in the individual fruit weight among treatments were observed $(\mathrm{p}<0.05)$. However, a slight tendency was observed in the bagged treatment, which showed a lower number of FDF but with higher weights than in those developed in open pollinated plants (Table 1). 
The mean air temperature during the third year was $21.4^{\circ} \mathrm{C}$ (Figure 1c). The lowest temperatures were observed after 95 and $114 \mathrm{DFE}$ with values of $5.4^{\circ} \mathrm{C}$ and $3.6^{\circ} \mathrm{C}$, respectively. Given that these low temperatures occurred after the end of the applied treatments, it is difficult to assure that they affected crop growth. Air temperature reached its maximum value $\left(38.7^{\circ} \mathrm{C}\right) 8$ and 9 days before FA ( 47 and 48 DFE), possibly inducing a moderate water stress in the plants. Temperature showed two maximums at the moment of pollen emission on days 62 and $63 \mathrm{DFE}$, between 6 and 7 days after the starting of FA with an average value of $32.8 \pm 1.0^{\circ} \mathrm{C}$ (Figure 1c).

\section{DISCUSSION}

The regulation of fruit development works not only at the level of the ovary development after the post-pollination and post-fertilization processes but also certain environmental factors are involved. It could be assumed that besides avoiding the contribution of pollen to other heads, the bagged treatments allowed self-fertilization to be protected from the harmful environmental factors (supra-optimum air temperature, high level of UV-B radiation), resulting in a similar number of fruits developed in the bagged and open heads.

Since plants under bagged and open treatments did not show significant differences in the number of IDF, the development of fruits could have been regulated by other compensatory intra-plant mechanisms, such as the generation of a higher number of IDF at the expense of the FDF. It should be pointed out that in the experiment of the first year, the number of FDF in the HA hybrid was lower in bagged heads than in open ones; however, the weight of these fruits was higher (Table 1). This fact might suggest the existence of the above mentioned compensatory mechanism. The same event occurred for the HB hybrid in the experiment of the third year (Table 1).

Regarding the hybrids used, no significant differences were observed in the number and individual weight of FDF. The lack of significant changes and even an increase in the number of FDF in the bagged treatments (Table 1) could also be explained by the occurrence of low temperatures during the pollination period that can trigger a higher level of self-compatibility in sunflower. In this way Pinthus (1959) found that a high percentage of self-fertilized fruits were generated in bagged plants under low temperature conditions during flowering. Thus, the author could demonstrate that bagged plants in autumn and spring produced between 50 and $60 \%$ and $0.4-0.5 \%$ fruits, respectively. This can be clearly seen in the HB hybrid during the experiment of the first year, where the number of FDF was higher in the bagged than in the open treatment (Table 1). The Figure la shows that for the first year the lowest minimum temperatures were recorded between FA and LA (Figure 1a). 


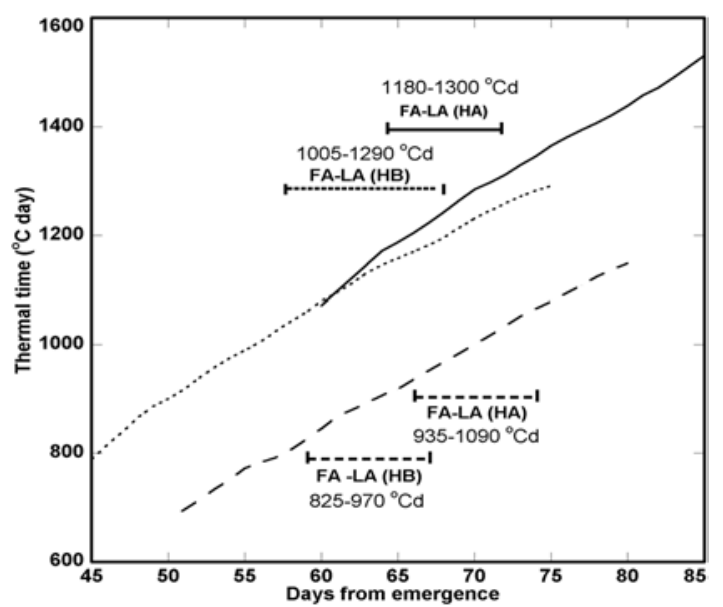

Figure 2. Accumulated thermal time $\left({ }^{\circ} \mathrm{C}\right.$-day) up to physiological maturity for the three years of the assay. The same legends as in Figure 1. The values of the intervals first anthesis-last anthesis (FA-LA) for each hybrid, indicate the magnitude of TT $\left({ }^{\circ} \mathrm{Cd}\right)$ in that period.

(- - - -: first year; ......... second year, HB hybrid;

—-: second year, HA hybrid).
During the first year, when the bagged plants showed no response to the absence of external pollination, the accumulated thermal time (TT; degree days $\left[{ }^{\circ} \mathrm{Cd}\right]$ ) between the first and last anthesis was lower for HB (range: 825-970 ${ }^{\circ} \mathrm{Cd}$; Figure 2) than for HA hybrid (range: $935-1090^{\circ} \mathrm{Cd}$; Figure 2). Similarly, temperatures recorded in the critical phase of fertilization (FA and LA) showed a similar difference, of a decreased magnitude, in the assays conducted in the second (HA) and third year (HB) (Figure 2). In this sense, the TT interval for $\mathrm{HB}$ in the third year was slightly shorter (range: $1005-1290^{\circ} \mathrm{Cd}$; Figure 2) than for HA hybrid (range: $1180-1300^{\circ} \mathrm{Cd}$; Figure 2).

\section{CONCLUSION}

The results obtained suggest that at least under the conditions in which the experiments were carried out, the absence of pollinators in the bagged plants did not limit sunflower yield and that genotype characteristics might play a relevant role in flower fertilization.

It can be inferred that the two hybrids used in this work showed a high selfcompatibility and that the differences in yield potential would be based on the effect of other physiological characters, not studied in the present experiments, on floret fecundation.

\section{ACKNOWLEDGEMENTS}

This work was funded by grants to L.F.H. by the Secretaría General de Ciencia y Tecnología (SeGCyT-UNS) and the Comisión de Investigaciones Científicas (CIC, La Plata) Argentina. V.A. holds a postgraduate scholarship from the Secretaría General de Ciencia y Tecnología (SeGCyT-UNS).

Authors want to thank Lic. C. Zotelo (CERZOS-CONICET) and Agr. Eng. M. Borda (Chacra Experimental de Barrow) for providing climate data and Agr. Eng. L. Gallez for helping with the french abstract. Sunflower seed was kindly provided by Monsanto of Argentina. 


\title{
REFERENCES
}

DeGrandi-Hoffman, G. and Chambers, M., 2006. The effects of honey bee (Hymenoptera: Apidae) foraging on seed set in self-fertile sunflowers (Helianthus annuus L.). Environmental Entomology 35: 1103-1108.

Dirienzo, J.A., Casanoves, F., Balzarini, M.G., Gonzalez, L., Tablada, M. and Robledo, C.W., 2008. InfoStat, versión 2008, Grupo InfoStat, FCA, Universidad Nacional de Córdoba, Argentina.

Fernández-Martínez, J. and Knowles, P.F., 1978. Inheritance of self incompatibility in wild sunflower. In: Proc. $8^{\text {th }}$ Intl. Sunflower Conf., Minneapolis, MN, 23-27 July 1978. Intl. Sunflower Assoc., Paris, France. pp. 484-489.

Iriarte, L.B. and Valetti, O.E., 1994a. Evaluación del grado de autogamia en cultivares híbridos de girasol (Helianthus annuus L.). INTA-CERBAS, Argentina. Informe Técnico No. 2, pp. 12 .

Iriarte, L.B. and Valetti, O.E., 1994b. Determinación del grado de ajuste del método utilizado para la evaluación de autocompatibilidad en girasol (Helianthus annuus L.). INTACERBAS, Argentina. Informe Técnico No. 3, pp. 18.

Lindström, L.I., García, M.E. and Hernández, L.F., 2004. Morphology and distribution of incompletely developed fruits in sunflower (Helianthus annuus L.) capitula. In: Seiler, G.J. [ed.], Proc. 16 ${ }^{\text {th }}$ Intl. Sunflower Conf., Fargo, ND, USA, 29 August-4 September 2004. Intl. Sunflower Assoc., Paris, France. pp. 333-337.

Pinthus, M.J., 1959. Seed set of self-fertilized sunflower heads. Agronomy Journal 51: 626.

Ploschuck, E.L. and Hall, A.J., 1995. Capitulum position in sunflower affects grain temperature and duration of grain filling. Field Crops Research 44: 111-117.

Schneiter, A.A. and Miller, J.F., 1981. Description of Sunflower Growth Stages. Crop Science 21: 901-903.

Snow, A.A., Moran-Palma, P., Rieseberg, L.H., Wszelaki, A. and Seiler, G.J., 1998. Fecundity, phenology, and seed dormancy of $\mathrm{F}_{1}$ wild-crop hybrids in sunflower (Helianthus annuus L., Asteraceae). American Journal of Botany 85: 794-801.

\section{UTOCOMPATIBILIDAD DE HÍBRIDOS MODERNOS DE GIRASOL (Helianthus annuus L.). CUAJADO DE LOS FRUTOS EN PLANTAS AUTOPOLINIZADAS (EMBOLSADAS) Y CON POLINIZACIÓN ABIERTA, CRECIDAS EN DOS SITIOS DIFERENTES.}

\author{
RESUMEN
}

El incremento en el rendimiento del girasol, debido a la participación activa de las abejas melíferas (Apis melifera L.) en la polinización, ha sido demostrado en estudios previos. Sin embargo, este hecho es más evidente en genotipos comerciales más primitivos. Otras evidencias sugieren que dicha polinización no sería necesaria en cultivares comerciales modernos, en los cuales existiría un alto nivel de autocompatibilidad.

El objetivo de este trabajo fue definir la capacidad de formación de frutos llenos (FDF) y de frutos de desarrollo incompleto (IDF) en dos híbridos modernos de girasol, expuestos a polinización cerrada y abierta.

Dos híbridos de girasol, uno de ciclo medio y otro de ciclo corto, definidos como HA y HB, respectivamente fueron sometidos a dos tratamientos de polinización: autopolinización (capítulos cubiertos con bolsas de malla fina antiáfidos desde la primera hasta la última antesis, evitando la acción de polinizadores) y polinización abierta (capítulos sin cubrir). 
El estudio se realizó durante tres años consecutivos en dos sitios diferentes. Las parcelas experimentales se ubicaron, el primer año en el Campo Experimental Barrow (Tres Arroyos; 38 $20^{\prime}$ S; $60^{\circ} 13^{\prime}$ O) y el segundo y tercer año en el campo experimental de la Universidad Nacional del Sur (Bahía Blanca; $38^{\circ} 45^{\prime} \mathrm{S}$; $62^{\circ} 11^{\prime} \mathrm{O}$ ), alcanzando en los tres periodos una densidad promedio de plantacion a la floracion de 60.000 plantas/ha. En el ensayo del segundo año los tratamientos se realizaron en el HA, y en el tercer año los tratamientos se realizaron en el HB.

El número de FDF y de IDF desarrollados en los capítulos, en los tres experimentos en los dos sitios no mostraron diferencias significativas entre los tratamientos. Se pudo observar una respuesta diferente no significativa en el número de FDF y de IDF entre diferentes años, la cual podría estar asociada a la temperatura ambiente en el intervalo de la antesis.

Se concluye que por efecto de un alto grado de autocompatibilidad, no existen diferencias en la generación de frutos llenos cuando se excluyen los polinizadores en las plantas de girasol de híbridos comerciales modernos.

\section{AUTO-COMPATIBILITÉ D'HYBRIDES MODERNES DE TOURNESOL (Helianthus annuus L.). MISE À GRAINE DES FRUITS DANS DES PLANTES AUTO-POLLINISÉS (ENFERMÉS EN SACS) ET AVEC POLLINISATION OUVERT, CULTIVÉS DANS DEUX SITES DIFFÉRENTS}

RÉSUMÉ

L'augmentation du rendement du tournesol, par la participation active des abeilles (Apis mellifera L.) dans la pollinisation, a été démontré dans des études antérieures. Cependant, ceci est plus évident dans les anciens génotypes. D'autres données suggèrent que la pollinisation ne serait pas nécessaire dans les cultivars modernes, dans lesquels il y aurait un niveau élevé d'autocompatibilité.

L'objectif de cette étude a été de définir la capacité de formation des fruits avec graine (DFF) et des fruits avec un développement incomplet (FDI) dans deux hybrides modernes de tournesol exposés à la pollinisation ouverte et fermée.

Deux hybrides de tournesol, l'un de cycle intermédiaire et l'autre de cycle court, défini comme HA et HB, respectivement, ont été soumis à deux traitements de pollinisation: l'auto-pollinisation (capitules couverts avec des sacs de filet anti aphidiens dès la première et jusqu'à la dernière anthese, en évitant l'action des pollinisateurs) et la pollinisation ouverte (sans couvrir les capitules).

L'étude a été menée sur deux sites pendant trois années consécutives. Les parcelles expérimentales ont été localisés, la première année à la station expérimentale Barrow (Tres Arroyos, $38^{\circ} 20^{\prime} \mathrm{S}, 60^{\circ} 13^{\prime} \mathrm{W}$ ) et les deuxieme et troisieme année à la station expérimentale de l'Universidad Nacional del Sur (Bahía Blanca, $38^{\circ} 45^{\prime} \mathrm{S}, 62^{\circ} 11^{\prime} \mathrm{W}$ ). Au moment de la floraison, la densite moyenne de plantes obtenue durant les trois années a eté 60.000 plants / ha. La deuxième année les traitements ont été effectués dans le HA, et la troisième année les traitements ont été effectués dans le HB. 
Le nombre de FDF et de FID développées dans les capitules, dans les trois expériences sur les deux sites n'ont pas montré aucune différence significative entre les traitements. Une réponse non significative a pu être observé dans le nombre de FDF et IDF entre les différentes années, qui pourrait être liée à la température ambiante dans la période de l'anthèse.

Nous concluons que du à l'effet d'un degré élevé d'auto-compatibilité, il n'y a pas de différences dans la production de fruits avec graine lorsque les pollinisateurs sont exclus, dans les plantes des hybrides commerciales modernes de tournesol. 